\title{
Response of the Dayak Basap Indigenous People on Settlement Relocation by PT. Kaltim Prima Coal in East Kutai District, East Kalimantan, Indonesia.
}

\author{
Dano Antonio Mapi \\ External Relations Office \\ J1. Dr. Sutomo No. 11 \\ Swarga Bara, Sangatta \\ Kabupaten Kutai Timur \\ Kalimantan Timur, 75611 \\ Indonesia
}

\begin{abstract}
The purpose of this study is to assess the response of Dayak Basap indigenous peoplein relation to the relocation process conducted by PT.KaltimPrima Coal (PT.KPC) from Keraitan village to new settlement area called Matiro Wali village. The massive expansion and exploitation of coal mining companies tend to create social issues and environmental impact on surrounding communities that caused the vanished of farmland and even land area for settlement. The expansion of coal mining project conducted by PT.KPC has caused the impacted Dayak Basap communities need to be relocated to other settlement area so that mining company could exploit the coal in accordance with the operating standard. In term of data collection, the researcher has interviewed 40 respondents by giving three options to express their responses to each question relating to the Dayak Basap resettlement "Satisfied", "Fair" and "Unsatisfied". The collected data is displayed in the form of a percentage (\%). Assessment aspects including relocation process such as housing, infrastructure development, road access, social and economic facilities, agricultural land, hunting and fishing areas, and the potential of future livelihoods. The result of this research is expected to be useful recommendation and reference for both corporations and local government officials in term of conducting resettlement of the local community living adjacent to coal mine areas. The researcher has found that Dayak Basap indigenous people strongly complain about the social and economic facilities provided by PT. KPC in the new settlement area due to the access road is badly damage, the limitation of agricultural land, hunting area and fishing ground are also insufficient.
\end{abstract}

Keywords: Dayak Basap, relocation, response, coal mining, PT. KPC, Keraitan\&MatiroWali.

\section{A. Introduction}

Dayak Basap is one of the many Dayak ethnic groups that inhabit the island of Borneo and are considered as indigenous people of this third biggest island in the world. The Dayak Basap group lives very close to the coal mine area (Pit) owned by PT. KPC, a coal mining company operating in the Bengalon sub-district, East Kutai Regency, East Kalimantan province. This group has inhabited this area for decades and even hundreds of years ago. They settled in a small hamlet deep in the forest called Dusun Keraitan, and due to the government policy through resettlement program in 1980s, then they moved to Segading hamlet which was located closer to the Bengalon sub-district. Based on oral histories from local Dayak Basap communities' leaders, the area that is now part of a coal mining concession (Coal Contract Of Work/CCOW) of PT. KPC, according to a permit from the government of the Republic of Indonesia, is the ancestral land of the Dayak Basap community group who has been occupying the area since hereditary. Social problems arise between Dayak Basap community and PT.KPC because of the space for these people movement is disrupted within their ancestral land as a result of mining expansion activities for the mining area due to the business interests of investors to pursue "Black Gold" alias coal which prices are currently very competitive in the world market.https://www.cnbcindonesia.com.

In term of business point of view, capitalists or business interests always defeat the weak (grass root / marginalized people). Entrepreneurs always make various ways to lobby the authorities to get permission (license to operate) for the success of their business purposes, even though there are parties who are economically and socially disadvantaged.Generally, habits and patterns of life of Dayak people, especially the Dayak Basap group from generation to generation are conducting traditional farming and hunting in forest areas which are their territory or customary rights from their ancestors. With the existence of coal mine that is getting closer to their settlements, the 
movement space of the Dayak Basap indigenous community is increasingly narrow. Hunting is increasingly difficult because forest areas have been cleared up for mining activities.

In addition, the Dayak Basap indigenous people that inhabit the Keraitan village adjacent to the mining area generally experience health problems.In other words, the quality of their health is very low. The responsibilities and attentions of the local government and the surrounding companies are still very limited. Dust and mud due to mining activities go into residential areas. Educational and health facilities were built only perfunctory, as if these Dayak Basap indigenous communities were considered as second prioritized citizens.

As we know that mining companies, both gold and coal mines, is always located in remote areas where the economic life of the communities around the mine area is generally less profitable, especially the availability of social and infrastructure facilities. By the presence of a coal mining company in an area will indirectly play an important role for the development of the area and certainly provides positive impact in term of social, economic and infrastructure development. Djadjadiningrat (2003) as cited in Siska (2013) stated that, the positive impact of coal mining activities are as sources of local revenue and foreign exchange, providing an important role in developing regions in Indonesia, such as opening roads in isolated areas due to mining activities. In addition, mining activities will also open employment opportunities for the community in the mining area.

However, based on the negative impact point of view, there are many people who argue that the mining company's activity is destructive action to the environment, both flora and fauna. Environmental issues such as water contamination and air pollution, noise and vibration become the main issues are faced by every coal mining company, including PT.KPC. Kusnoto and Kusumodirdjo (1995) as cited in Qomariah (2003) stated that, mining activities are not only providing a positive impact in the form of increasing foreign exchange but also have a negative impact on the environment such as decreasing soil productivity, soil compaction, erosion and sedimentation, and disruption of flora and fauna and local community comfort.

Because of the various disruptions to economic and the environmental conditions such as air pollution, agricultural land that the company exploits, hunting and fishing areas are disturbed, then PT. KPC offers the Dayak Basap community for being relocated from their previous village in Keraitan to the new settlement called MatiroWali in the hope that their quality of life will be better than in their previous settlement with adequate land for agriculture, representative housing, better road access, and various promises from the company so people want to move. The settlement relocation program is expected to improve the living standards of the Dayak Basap indigenous communities to be much better than before, from some aspects such as the environmental condition, social, economy, residential area and future aspects of the young generation. According to Indonesia Law No. 4 of 1992 concerning Settlements, it is stated that settlements are part of the environment outside protected areas, both in the form of urban and rural areas that function as residential or environments as well as places of activities that support people's lives.

Coal mining company operating in this area is PT. Kaltim Prima Coal (PT.KPC), which was starting its business of coal mining since 1982 in East Kutai District. Infrastructure development began in 1986 and continued with mining activities in early 1990 and started for the first time exported coal in 1991.Initially PT. KPC was a jointly owned by Rio Tinto Australia and British Petroleum, UK with 50\%:50\% shareholding composition. This was in accordance with the agreement of the Government of the Republic of Indonesia through the Coal Mining Concession Working Agreement (PKP2B) commonly referred to as Coal Contract of Work (CCOW). However, in 2003, PT.KPC was taken over by the Indonesian Private Company PT. Bumi Resources.

The total area of the PKP2B/CCOW is around 100,000 hectares which covers the sub-district territories of Sangatta and Bengalon. In its development, the agreed area (Agreement Area) was reduced to approximately 90,667 hectares. This shrinking is conducted due to the area is included in the National Park area. In addition, more and more people who live within the PKP2B area and potentially have to generate social conflict.The existence of this company in both Sangatta and Bengalon areas, is actually enough to have a positive impact on the economic and social development of local communities. Infrastructure development and the involvement in supporting social activities have been widely practiced.

PT.KPC has been planning and carrying out the resettlement program of the Dayak Basap indigenous people since 2009, however, until now the resettlement has not been successfully implemented as planned. Construction of public facilities and infrastructure in the new settlement area has not been implemented properly. Access roads and residential area are still not looking neatly arranged. Most of the Dayak Basap people have not yet gone to the new settlement in the village of MatiroWali because public facilities are inadequate. It seems that PT. KPC is not committed to what it has been promised to the Dayak Basap community. Due to the condition of public facilities construction at the new settlement site has not yet completed by PT. KPC, there were some Basap families who had moved to MatiroWali go back to their previous village in Keraitan. 


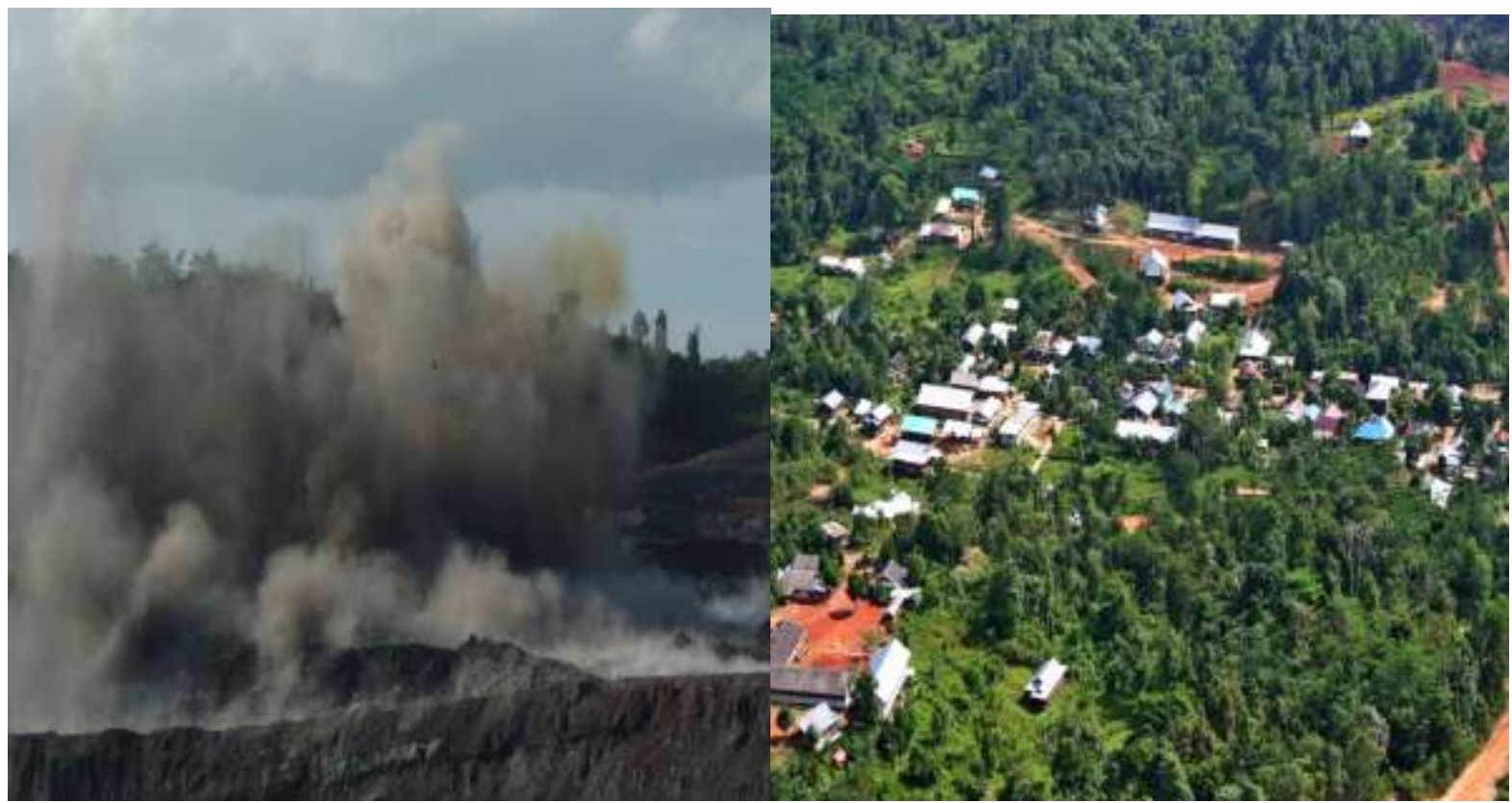

Mining activity (blasting) close to Dayak Basap Keraitan village (Basap old village) Settlement site.

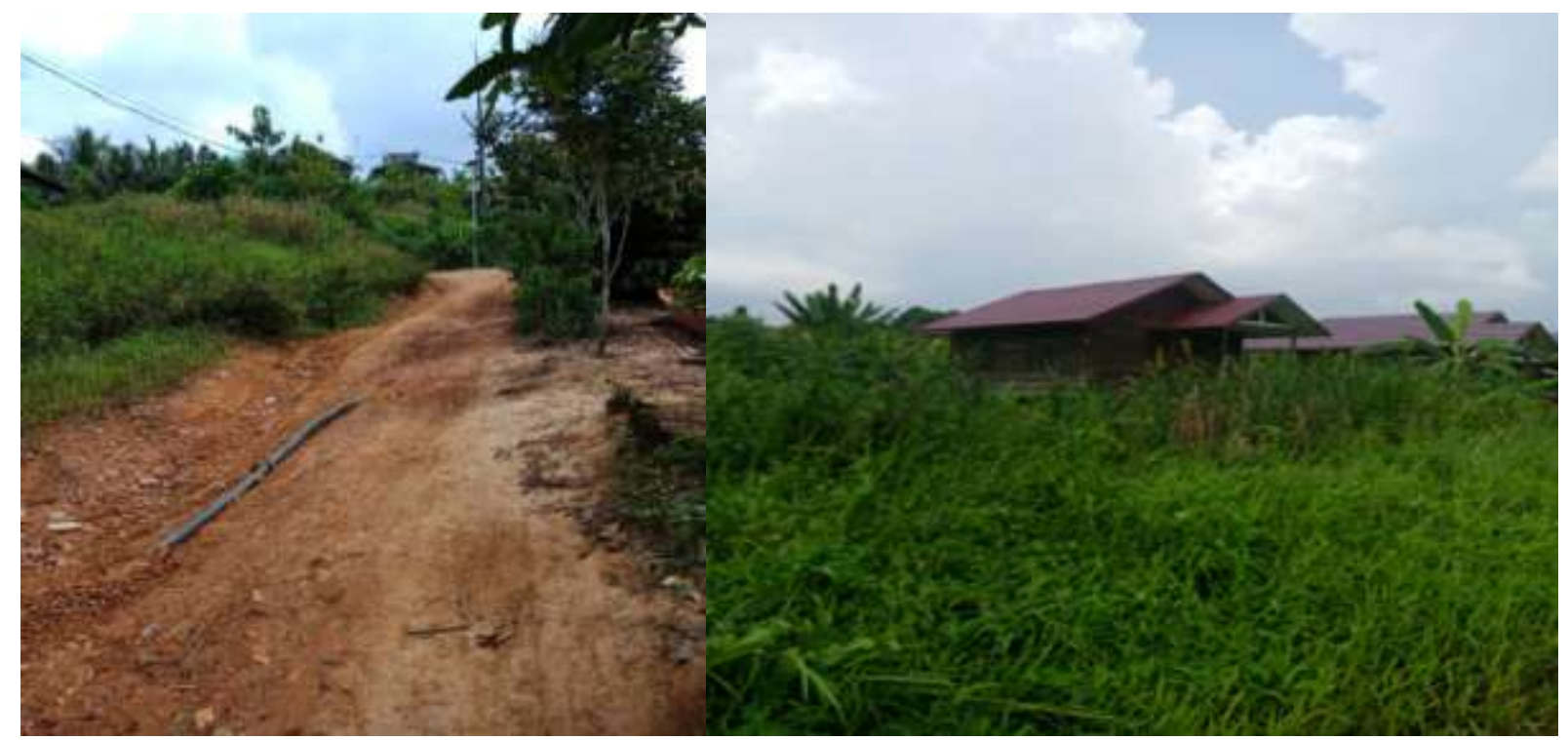

Access road built by PT.KPC

Dayak Basap's houses in MatiroWali.

Prepared by PT.KPC

\section{B. Methodology}

\section{Research Method}

The method used in this study is qualitative research, which is aiming to describe the response of Dayak Basap residents being relocated by PT.KPC since its mine activity is getting closer to their residential area. This research method is also intended to describe the phenomena that occur during the relocation or resettlement process is going on.This qualitative research was conducted in February to April 2019 by interviewing the Dayak Basap residents randomly in both MatiroWaliand Keraitan villages, Sub-District of Bengalon, East Kutai District. MatiroWali is a new settlement and was prepared by PT.KPC for being resided by indigenous Dayak Basap residents from their previous village in Keraitan. Matiro Wali, a new settlement is located around $22 \mathrm{~km}$ away from the old settlement in Keraitan and $4 \mathrm{~km}$ away from Bengalon, the Capital City of Bengalon sub-district.The reason of relocation was because of their old village would be severely impacted by the coal mining exploration and exploitation especially blasting activity. 


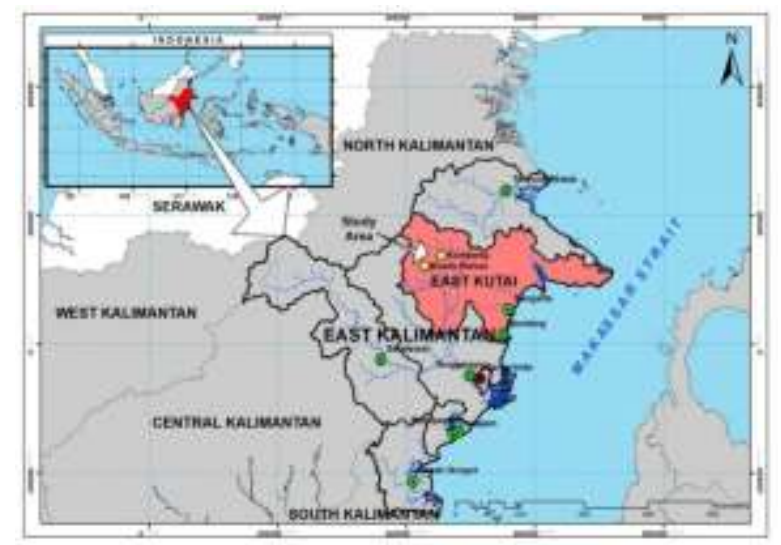

\section{Research site is in Bengalon sub-district, East Kutai regency, East Kalimantan province.}

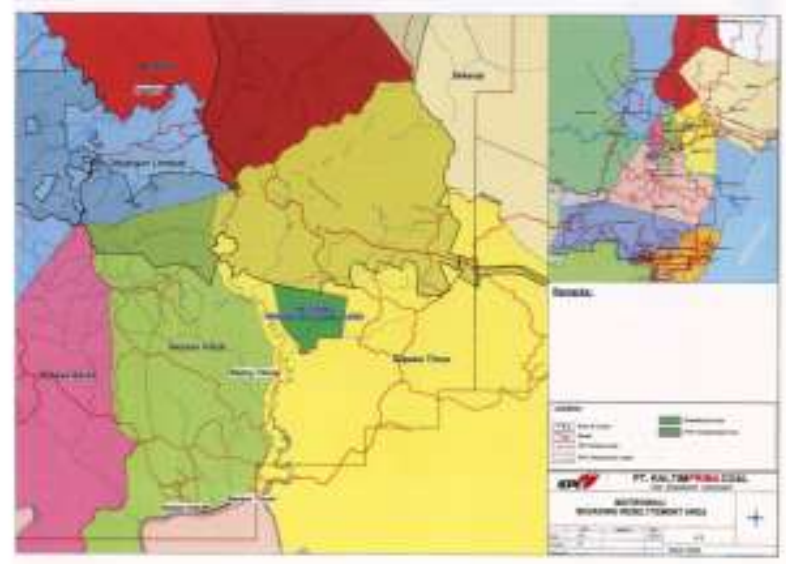

PT.KPC's map of mine location proposed to be mined for ten years onward.

\section{Communication Theory and Paradigm}

In this study, the researcher used socio-cultural communication theory and constructivism paradigm. The researcher uses the constructivism paradigm in this research because to relocate the Dayak Basap settlement it requires the study of social science as a systematic analysis of socially meaningful actions through direct and detailed observation in the field by social actors in the regulation of the relocation process, in order to understand and interpret how social actors concerned is able to create and maintain the social world of society as it should be.

According to Grifin and Emori (2012), Socio-Cultural theory departs from anthropological studies, namely that communication takes place in certain cultural contexts. Therefore, communication is influenced by the culture of a society. The mass media, or individuals when carrying out communication activities are also determined by certain situational factors. Socio-cultural theory emphasizes ideas and is interested in learning about the ways in which people together create the reality of their social, organizational and cultural groups. Socio-cultural is used in topics about individuals, conversations, groups, organizations, media, culture and society. In connection with the relocation of indigenous Dayak Basap people by PT. KPC, an understanding of the socio-cultural aspects of the local community is very important so that communication between the two parties can proceed properly and there is no conflict of interest.

\section{Data Sources and Sampling}

Data and sampling were collected by interviewing respondents selected randomly from the Dayak Basap residents. Research site was selected purposively because it was an indigenous settlement that being relocated to other area due to the expansion of coal mining exploitation. The numbers of respondents were $60 \%$ of 68 households or 40 respondents that were selected using simple random sampling method. Data and information needed among others were the response to socio-economic condition in the new settlement in MatiroWali Village. Other data sources were the Village Head (Kepala Desa), Customary Head (Kepala Adat), representative of young people and women and other keypersons in the Dayak Basap community. They were interviewed through in-depth interview method. 


\section{Data analysis}

Data were analyzed qualitatively. Data from the respondents' answers is calculated as a percentage of each answer. Qualitative data is analyzed by collecting data, compiling, using and interpreting the data collected then described completely, orderly and thoroughly so that it can provide a clear and accurate description of the phenomenon being researched.

For the first purpose, the analysis is being carried out about the community's opinion, namely their opinion on the ongoing relocation process, the criteria for new settlement according to the Dayak Basap residents and their expectations regarding the ongoing relocation process. The second purpose, the analysis is carried out on the conditions of the relocation destination in the form of physical, social and economic conditions. Physical conditions consist of housing, clean water, electric city, sanitation and roads. Economic conditions are in the forms of agricultural and livelihood status. Meanwhile the social conditions are in the form of the availability of social and public facilities.

\section{Results and Discussion}

\section{Description of relocation.}

The Matiro Wali village location is located in another residential area with less extensive land and forest areas unlike in their home village in Keraitan. The land area prepared by the coal mine company (PT.KPC) to be used as a residential area and agricultural land is around 200 hectares. The ownership of this agricultural land is not yet clear, so the residents are hesitant to farm on the land provided. According to the Dayak Basap residents, road access from the main road to the new settlement is in a badly damaged condition so that the community is very difficult to enter and exit the village area towards the Capital of Bengalon Sub District, particularly during the rainy season.

Another problem arises relating to this relocation program is that there are still pro and contra among Dayak Basap residents with this relocation program due to the land compensation payments in their place of origin in Keraitan village have not yet been paid off by PT. KPC. In addition, the Dayak Basap residents' scope of activities in Matiro Wali is also considered very limited, especially the space for hunting movement or mobility and others. As a result, there were several Basap residents who returned to their previous village in Keraitan so that several houses were left vacant in MatiroWali.

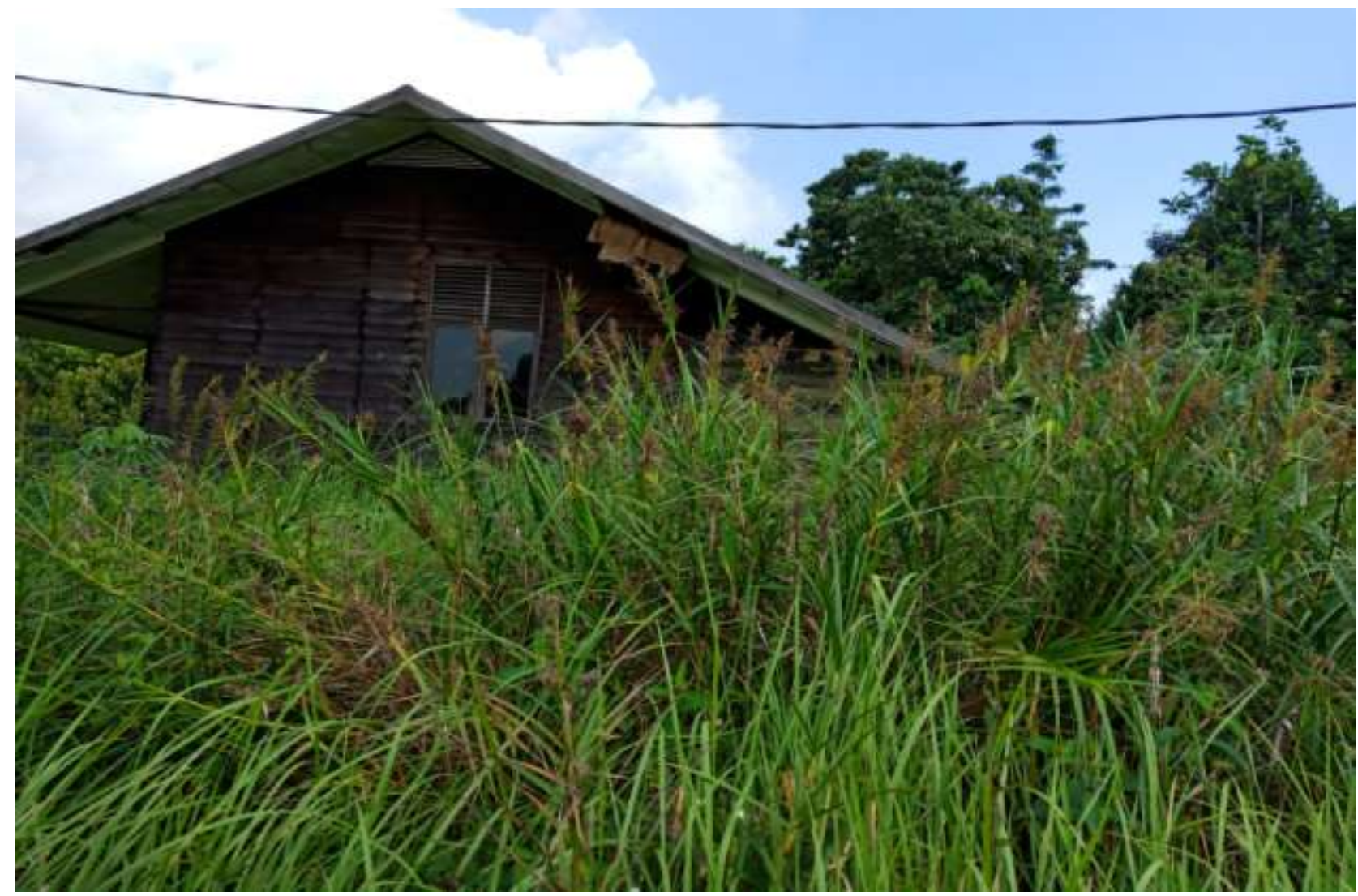

The Dayak Basap's house in the village of Matiro Wali without occupants 


\section{Process of relocation.}

Relocation means the process of moving residents and all of their property (livestock, goods, and all possessions owned) from the original village in Keraitan to the new relocation site in Matiro Wali.The aspects studied were whether the company helped the village to move their people, livestock and all property satisfactorily or not, or maybe the community was told to move on their own. Another aspect is whether the community is given a comprehensive information about the purpose of relocation, the rights and obligations of the Dayak Basap residents in the new location settlement.The research results are as follow:

Table1. Response to the relocation process

\begin{tabular}{lllll}
\hline \multirow{2}{*}{ No } & Questions to respondents & \multicolumn{3}{c}{ Response (\%) } \\
\cline { 3 - 5 } & & Satisfied & Fair & Unsatisfied \\
\hline 1 & $\begin{array}{l}\text { Did you well informed to the purpose of the } \\
\text { relocation? }\end{array}$ & 43 & 41 & 16 \\
2 & $\begin{array}{l}\text { Did company helpyou in transporting all of your } \\
\text { property to new settlement? }\end{array}$ & 20 & 35 & 45 \\
3 & $\begin{array}{l}\text { Did you move to the relocation village willingly? } \\
\text { Total }\end{array}$ & 30 & 30 & 40 \\
\hline & Average & $31 \%$ & $35 \%$ & $33 \%$ \\
\hline
\end{tabular}

Source: field observation (2019)

Data on table above indicates that the villagers were informed enough of the process of relocation for example the condition of the new village to live in and the responsibility of the company to the people in new relocation area. Some $31 \%$ of people also consider "satisfied" and some 35\% were "fair" of the relocation process. However, some $33 \%$ still unsatisfied of the process of relocation. Due to the well- informed of the relocation plan, around 35\% felt that the process was fair enough for the Dayak Basap indigenous people to be relocated.

\section{Response to housing construction}

Before the DayakBasapresidents were relocated to MatiroWali, the company had promised them for better house buildings or settlement facilities that were more feasible than the condition of the houses in their previous village in Keraitan. According to Turner (1976) in Musthofa (2011) one of the functions of the house is to support the family identity which is manifested in the quality of housing so that residents have a place of refuge. Houses as supporting opportunities for families to develop in social, cultural and economic life are manifested in the ease of access to workplaces to earn income.

Table 2. Response to housing construction

\begin{tabular}{lllll}
\hline \multirow{2}{*}{ No } & Questionsto respondents & \multicolumn{2}{c}{ Response (\%) } \\
\cline { 3 - 5 } & & Satisfied & Fair & Unsatisfied \\
\hline 1 & Do you feel comfortable living in your house? & 57 & 28 & 15 \\
2 & How about the quality of house material? & 48 & 43 & 9 \\
3 & How about the drainage of the settlement area? & 14 & 67 & 19 \\
4 & Do you have certificate of your house? & 0 & 0 & 100 \\
5 & What is your response to the overall condition of the & 43 & 40 & 17 \\
& settlement? & 16 & 50 & 34 \\
6 & How about the availability of drinking water? & 9 & 57 & 34 \\
\hline & How about sanitation condition in new settlement? & 187 & 285 & 228 \\
\hline \multicolumn{2}{r}{ Total } & $26.7 \%$ & $40.7 \%$ & $32.5 \%$ \\
\hline
\end{tabular}

Source: field observation (2019)

Table 2 above shows that most (26.7\%) of the villagers feeling comfortable living in their houses because the quality of the house is good enough and meet with their expectation. $40.7 \%$ respondents feel fair and $32.5 \%$ feel unsatisfied.In terms of drainage, sanitation and drinking water, most of the villagers put their response to "fair" and only a few respondents feeling "satisfied" with such conditions. The inconvenience conditions caused some people returned to their old village in Keraitan in which they feel more comfortable to live in and more opportunities for hunting and fishing. 
Most of the Dayak Basap residents feel unsatisfied with the overall existing socio-economic conditions in the new settlement site because they have lower income in new socio-economic conditions compared to their previous village. This is caused by many of facilities that are unavailable in the new settlement location.

\section{Response to social and economic life}

Income generation is the interventions attempt to address poverty, unemployment, and lack of economic opportunities to increase villagers' ability to generate income and secure livelihoods.This part will review the social and economic conditions of the Dayak Basap residents by comparing them to the socio-economic conditions in the village of their origin in Keraitan.

Table 3. Response to the economic life

\begin{tabular}{|c|c|c|c|c|}
\hline \multirow[t]{2}{*}{ No } & \multirow[t]{2}{*}{ Questions to respondents } & \multicolumn{3}{|c|}{ Response (\%) } \\
\hline & & Satisfied & Fair & Unsatisfied \\
\hline 1 & $\begin{array}{l}\text { What is your response to the availability of livelihood } \\
\text { in the village? }\end{array}$ & 5 & 54 & 41 \\
\hline 2 & $\begin{array}{l}\text { What is your response to household income in new } \\
\text { settlement? }\end{array}$ & 9 & 56 & 39 \\
\hline 3 & What do you think of the economic future here? & 10 & 51 & 49 \\
\hline 4 & $\begin{array}{l}\text { Compared to old village, what is your response to } \\
\text { economic life here? }\end{array}$ & 7 & 43 & 50 \\
\hline \multirow[t]{3}{*}{5} & $\begin{array}{l}\text { How about the availability of social facilities in the } \\
\text { new relocation site? }\end{array}$ & 5 & 29 & 66 \\
\hline & Total & 36 & 233 & 255 \\
\hline & Average & $7.2 \%$ & $46.6 \%$ & $49 \%$ \\
\hline
\end{tabular}

Source: field observation (2019)

Social and economic infrastructures including educational facility (school), health facility (Public Health Centre), village hall, and other public facilities. Table 3 above indicates that the residents' responses to the economic life is low where the villagers not satisfied with the availability of livelihood in the relocation area with only $7.2 \%$ respondents feel satisfied with the existing economic life condition, $46.6 \%$ feel fair and $49 \%$ feel unsatisfied with all conditions, especially due to the limitation of agricultural area as well as the bad quality of the accessibility.

\section{Response to access of agricultural land}

For the Dayak Basap indigenous people, the main work and income are coming from traditional farming, hunting and gathering forest products activities which are their way of life for generations. Therefore, access to agricultural land is very important.

Access to agricultural land includes the distance to agricultural land, availability of fertile land for agriculture or traditional farming, access/road to agricultural field, and the rights over land.

Table 4. Response to agricultural land area

\begin{tabular}{|c|c|c|c|c|}
\hline \multirow[b]{2}{*}{ No } & \multirow[b]{2}{*}{ Questions to respondents } & \multicolumn{3}{|c|}{ Response (\%) } \\
\hline & & Satisfied & Fair & Unsatisfied \\
\hline 1 & $\begin{array}{l}\text { What is your response to the availability land for } \\
\text { farming? }\end{array}$ & 16 & 31 & 53 \\
\hline 2 & Is the land fertile enough for farming? & 28 & 53 & 19 \\
\hline 3 & $\begin{array}{l}\text { Is access road to the land easy for you to go } \\
\text { through? }\end{array}$ & 46 & 43 & 11 \\
\hline \multirow[t]{3}{*}{4} & Are you sure to have the right over land provided? & 9 & 14 & 77 \\
\hline & Total & 99 & 141 & 160 \\
\hline & Average & $24.7 \%$ & $35.2 \%$ & $40 \%$ \\
\hline
\end{tabular}

Source: field observation (2019)

Data on Table 4 indicates that the availability of agricultural land area is considered "unsatisfied", that is only 200 ha which is much narrower compared to their agricultural land in their village of origin in Keraitan Village. In term of agricultural land aspect such as access to farming areas and land fertility in the new settlement location, some $24.75 \%$ respondents think satisfied, $35.25 \%$ respondents say fair and $40 \%$ feel unsatisfied or less satisfied with the agricultural land areas and existing accessibility. 
In average, $40 \%$ of the respondents consider that the access to agricultural land is "unsatisfied". They do expect that the company will help them to improve access to their farming land. This is in line with Pandia et al (2016) who described that the relocated people of Sinabung volcano eruption in Tana Karo Indonesia needed not only new houses but also the most important thing are agricultural land areas because most of them were farmers in their old village. They do not want to be relocated without agricultural land availabilities.

\section{Response to infrastructure and road development}

Inadequate infrastructure development is one of the problems faced by the local residentsin term of developing economy in the village. The damaged roads are difficult to pass through during the rainy season become the main obstacles toBasapDayak residents to selltheir agricultural products and hunting results or non-timber forest products to market.

Table 5. Response to infrastructure \& road development

\begin{tabular}{|c|c|c|c|c|}
\hline \multirow{2}{*}{ No } & \multirow{2}{*}{ Questions to respondents } & \multicolumn{3}{|c|}{ Response (\%) } \\
\hline & & Satisfied & Fair & Unsatisfied \\
\hline 1 & $\begin{array}{l}\text { What is your response to the land access } \\
\text { availability from the village to economic center? }\end{array}$ & 0 & 19 & 81 \\
\hline 2 & $\begin{array}{l}\text { What is your response to the road condition and } \\
\text { accessibility in rainy season? }\end{array}$ & 0 & 10 & 90 \\
\hline \multirow[t]{3}{*}{3} & What is your response to the quality of the road? & 0 & 13 & 87 \\
\hline & Total & 0 & 42 & 258 \\
\hline & Average & $0 \%$ & $14 \%$ & $86 \%$ \\
\hline
\end{tabular}

Source: field observation (2019)

None of the villagers or respondents have agreed and satisfied with the existing infrastructure and road development.Data on table 5 indicates that most of the villagers $(86 \%)$ put the response "unsatisfied' to the land transportation to the settlement relocation. They complain that the road is very bad condition, especially during wet season, therefore it is very difficult for villagers to go to economic center in Bengalon Sub-district as well as to Sangatta as the Capital City of East Kutai Regency. There's no "satisfied" response to the road and infrastructure development. The villagers complained that the existing road could not be passed through during rainy season. They ask both PT.KPC and local government to pay attention for the social infrastructure improvement. Meanwhile, PT.KPC will think twice since this will spend a lot of budgets.

\section{Access to hunting and fishing areas}

The Basap Dayak indigenous community cannot be separated from hunting and gathering forest products because it has been a way of life for generations. In the village of Keraitan, there is a large forest area for hunting with various types of animals such as deer, boars, mouse-deer and fish in a river within the Keraitan village. This aspect is discussing about the response of the Basap people to access for hunting and fishing compared to their access in their old village Keraitan.

Table 6. Access to hunting and fishing areas

\begin{tabular}{|c|c|c|c|c|}
\hline \multirow[t]{2}{*}{ No } & \multirow[t]{2}{*}{ Questions to respondents } & \multicolumn{3}{|c|}{ Response (\%) } \\
\hline & & Satisfied & Fair & Unsatisfied \\
\hline 1 & Do you have accessible hunting ground? & 11 & 31 & 58 \\
\hline 2 & Do you have any fishing area in this village? & 19 & 32 & 49 \\
\hline 3 & Is there any animal for hunting here? & 6 & 29 & 65 \\
\hline 4 & Do you satisfy with animal being captured? & 6 & 28 & 66 \\
\hline \multirow[t]{3}{*}{5} & $\begin{array}{l}\text { Compared to old village, which one is better for } \\
\text { hunting? }\end{array}$ & 0 & 11 & 89 \\
\hline & Total & 42 & 131 & 327 \\
\hline & Average & $8.4 \%$ & $26.2 \%$ & $65.4 \%$ \\
\hline
\end{tabular}

Source: field observation (2019)

Likely other aspects, most of the respondents (65.4\%) consider that access to hunting and fishing ground is "unsatisfied", around 26.2\% "fair" and only $8.4 \%$ feel satisfied with access to hunting ground. As mentioned above, the relocation area is surrounded by other existing villages so that hunting ground and fishing area are limited. Other limitation to hunting and fishing areas are due to expansion of oil palm plantation and there's no big river nearby for fishing. In their old village in Keraitan, they had one big river for fishing which can supply the need of fishes. 


\section{Access to forest products and Non-Timber Forest Product (NTFP)}

As mentioned above that the indigenous Dayak Basap people were traditionally depending on forest products and nontimber forest products such as rattan, aloes trees (gaharu), resin, mushroom, roots and wild animals. Recently before they were relocated to the new settlement they still had access to forest and NTFP even though the quantity was decreased significantly due to expansion of coal mining and oil palm plantation.

Table7. Response to timber and non-timber forest products

\begin{tabular}{|c|c|c|c|c|}
\hline \multirow[t]{2}{*}{ No } & \multirow[t]{2}{*}{ Questions to respondents } & \multicolumn{3}{|c|}{ Response (\%) } \\
\hline & & Satisfied & Fair & Unsatisfied \\
\hline 1 & $\begin{array}{l}\text { What is your response to the forest area for collecting } \\
\text { non-timber forest products? }\end{array}$ & 8 & 32 & 60 \\
\hline 2 & $\begin{array}{l}\text { What is your response to the availability of non- } \\
\text { timber forest products? }\end{array}$ & 6 & 28 & 66 \\
\hline 3 & What is your response to the timber forest products? & 7 & 27 & 66 \\
\hline 4 & $\begin{array}{l}\text { What is your response to the availability of plants for } \\
\text { herbal medication? }\end{array}$ & 27 & 49 & 26 \\
\hline \multirow[t]{3}{*}{5} & $\begin{array}{l}\text { How about the need of herbal for traditional } \\
\text { medication? }\end{array}$ & 28 & 50 & 22 \\
\hline & Total & 76 & 186 & 240 \\
\hline & Average & $15.2 \%$ & $37.2 \%$ & $48 \%$ \\
\hline
\end{tabular}

Source: field observation (2019)

Table 7 shows that $48 \%$ of the villagers think that the forest areas for collecting non-timber forest products in the new settlement are "unsatisfied" compared to their old village in Keraitan. This is because of the new relocation area is surrounded by other earlier settlements so that the area is limited. In terms of herbal for traditional medication, the respondents satisfied $15.2 \%$ and $37.2 \%$ say "fair" because the herbal needed for medication can be found in the secondary forest nearby village.

\section{Reasons of some villagers insisted to remain staying at their old village of Keraitan}

As mentioned earlier that not all the Dayak Basap residents are willingly to move to the new settlement (relocation area) provided by the PT.Kaltim Prima Coal (PT.KPC), even though the company has already built houses for those villagers. The reasons for not to move are:

(1) If they move to MatiroWali, then the identity of the Keraitan village is lost, because the Matiro Wali area is part of the East Sepaso village; (2) Facilities at Matiro Wali are also not fully provided; (3) PT. KPC offer swap scheme for existing houses in the old village with new ones in the new relocation site without intending to set up compensation payments for the existing crops and housesin the old village; (4) Former Chief of Customary and also former of Village Head of Keraitan village Mr. Pasak(95 years old) will not move for any reason because he tied emotionally and environmentally with Keraitan area; (5) There are some residents who want to move to MatiroWalias as long as their lands, plants and houses are paid by PT.KPC; (6) some residents who have moved to MatiroWali, returned to Keraitan because in the new settlement it is difficult to find out income such as farming, hunting, fishing, plus access roads are severely damaged; (7) KPC is no longer coming to Keraitan as it once was, especially medical visits for the villagers.

\section{Further concern of PT.KPC to improve economic life for the Dayak Basap Indigenous Community.}

Despite the complain of the community to the resettlement, as a large national company, PT. KPC continues to show its concern for the Dayak Basap indigenous people in this area that used to be classified as isolated Indigenous Communities. Therefore, the company has prepared two development options, namely: (1) paying compensation for all growing crops and houses belonging to the Dayak Basap residents in their old settlement Keraitan village so that they all will be ready to move to the new settlement in the Matiro Wali village; (2) build a new road for residents in Keraitan Village so that they do not pass through their previous access road because it has been crossed by the coal hauling road.

From the two options, based on in-depth interview, residents prefer to the second option, which is to build a new road from Keraitan village to the main road so that residents do not need to move but still have smooth access to the economic center in the Bengalon sub-district and to Sangata, the capital city of East Kutai District. 
However, through field observation to compare the advantages and disadvantages of the two options above, the researcher found that it is also realistic if the company still allows Keraitan people to use the old access-road as long as security of the company can secure the safety of people who are crossing the road used by company (PT.KPC) for exploitation and coal hauling truck. This option will give big advantage for company because the company does not necessary to expend big money to build new road.

\section{Conclusions}

(1) The Dayak Basap community complained about the social economic condition in the new settlement of Matiro Wali. They also complained about the bad access road to village/relocation area, the limitation of agricultural land that only $200 \mathrm{ha}$, limitation of hunting and fishing ground. The uncertainty rights over the agricultural land and houses also caused the villagers feel unhappy to live in the new settlement area.

(2) The responses of the respondents to some aspects of social and economic conditions in the new settlement site are mostly not satisfied with the existing public facilities condition. For example some $26.7 \%$ satisfied, $40.7 \%$ think fair and $32.5 \%$ respondents say unsatisfied to housing development area. In term of economic life around $46.6 \%$ "fair", $49 \%$ "unsatisfied" and only 7.2\% feel "satisfied' with economic life in the new settlement; access to agricultural land also not satisfy the respondents because the size is limited; development of road to relocation area is the most complained aspect by villagers because the road is very bad so that it could not be passed through in rainy season; hunting and fishing are the traditional ways of life of the Dayak Basap indigenous communities, so that they are not satisfied with the new relocation area since there are no hunting and fishing ground accessibilities.

(3) KPC's responsibility in implementing relocation has not been carried out well, starting from socialization, communication with related stakeholders and basic facilities at the new settlement area. Therefore, residents were disappointed because the follow-up of the development was not in accordance with what was expected by the residents and as being promised by PT. KPC, for example clean water, health \& school facilities and social development. Likewise, from the economic aspect and access to farming land and forests, most residents feel unsatisfactory.

(4) There were no significant life changes for the Dayak Basap indigenous communities relocated by PT.KPC. Unchanged but the costs are skyrocketing, meaning that PT.KPC has spent a lot of money for resettlement program, however, the result is unsatisfactory. Therefore, PT.KPC needs to review the resettlement strategy being implemented.

\section{E. Recommendation}

(1) In term of relocating the Dayak Basap people to the new settlementarea successfully, PT.KPC should focus on the development of social and economic facilities and empower them for other aspects of life in order to improve their living standard to be much better than before. For example, education and health facilities, the development of good road so that the people have good access to social and economic center.

(2) Due to the limitation of agricultural land, hunting and fishing ground, PT.KPC should provide the Dayak Basap youths with agricultural training to increase their knowledge and skills on land productivity, raising livestock and fish pond, etc. For the Basap young people, the company should provide trainings that meet the work opportunity requirements set by both government and companies operating around the area.

(3) Communication and relationship between PT.KPC, Dayak Basap, and other related stakeholders need to be improved in order to succeed the relocation or resettlement program. If communication is not running well, then this resettlement of the Dayak Basap will fail although PT.KPC has spent amount of big money.

(4) KPC needs to focus on community empowerment by fostering in the socio-economic fields which is useful for improving the Dayak Basap community living standard. Health, education and public facilities in the new settlement area need to be focused on.

(5) Most of Dayak Basap residents prefer to the second option, which is to build an access road from Keaitan village to Bengalon sub-district instead of relocating them to MatiroWali, a new settlement area prepared by PT.KPC. Therefore, KPC needs to consider this option since the costs may be much cheaper compare to conduct the Dayak Basap resettlement.

(6) PT.KPC needs to involve the local government officials and related stakeholders in term of relocating the Dayak Basap indigenous communities successfully. If not, it can be a social issue both national and international issues, and mining impact on the locals that potentially harm the company image and reputation.

\section{References}

Colistra, Rita. (2018). Power Pressures and Pocketbook Concerns: Perceptions of Organizational Influences on News Content in the Television Industry. International Journal of Communication 12(2018), 1790-1810. 
Coppini, David; German,Alvares;\& Hernando, Rojas. (2018). Entertainment, News, and Income Inequality:How Colombian Media Shape Perceptions ofIncome Inequality and Why It Matters. International Journal of Communication 12(2018), 1651-1674.

Creswell, J.W; \&Porth,C. (2018). Qualitative Inquiry \& Research Design Choosing Among Five Approaches $\left(4^{\text {th }}\right.$, ed). California, USA: Sage Publications,Inc.

External Affairs and Sustainable Development Division; KPC, PT. (2014). Laporan mplementasi Tanggung Jawab Sosial.

Milles, Matthew, B. (2014). Qualitative Data Analysis. A Methods Sourcebook.

Pandi, Stenfri Loy; Rachmawati, Rini; \& Mei, E.T Wulan. (2016). Relokasi Permukiman Desa Suka Meriah Akibat Kejadian Erupsi Gunung Api Sinabung Kabupaten Karo. Jurnal Perencanaan Wilayah dan Kota (Journal of Regional and City Planning) vol. 27, no. 2, pp. 137-150, August 2016.

PT.Kaltim Prima Coal. (2014). External Affairs \& Sustainable Development Division. Laporan Implementasi Tanggung Jawab Sosial.

Wuryandari, Retno; Hendrayana,Heru; \&Karnawati, Dwikorita. (2005). Kelayakan Pemanfaatan Lahan Bekas Tambang Batubara untuk Relokasi Permukiman Penduduk: Studi Kasus areal Tambang Pt. Kitadin Kabupaten Kutai Kartanegara Provinsi Kalimantan Timur (Feasibility of Former Coal - Mined Land For Resettlement). Manusia dan Lingkungan, Vol. 12, No.l, hal. 20-27. Pusat Studi Lingkungan Hidup Universitas Gadjah Mada. Jogyakarta.

Yunarto; \&Sari, A.M. (2017). Relokasi Penduduk Terdampak Banjir Sungai Di Kota Semarang.

Zaini, Musthofa. (2011). Evaluasi Pelaksanaan Relokasi Pemukiman Kumuh di Kecamatan Jebres Surakarta. Tugas Akhir, Universitas Sebelas Maret, Surakarta. 